\title{
A NOTE ON THE SPECIES OF FUCELLIA OF EASTERN NORTH AMERICA.
}

\section{By Charles W. Johnson.}

I have been greatly interested in the paper by Prof. P. Stein, "Zur Kenntnis der Gattung Fucellia Rob. Desv.," (Wiener Entom. Zeit., XXIX, p. 11, 1910). A study of all the material at hand (over 60 specimens), shows that all are referable to Fucellia marina Macq. and not to $F$. fucorum Fall. In referring to the distribution of the latter in Europe, Prof. Stein says:- "The true F. fucorum, as Lundbeck comprehends in his "Diptera groenlandica," is found very rarely on our German coasts and belongs more to the far North. I did not find it in any collection of my dipterological friends, for all that were sent to me under the name fucorum belonged to maritima Hal. I myself caught only a single male in Thiessow on the Island of Ruegen, together with maritima Hal. But as I took with it comparatively few specimens, that $I$ at that time held for the same species, it is possible that after all fucorum is also more abundant on Ruegen. On our Baltic coasts I have never yet observed it. When Lundbeck declares that the species is spread over the greater part of Europe as far as Trieste, this rests on the assumption that the fucorum quoted by the author is Fallen's species, which is, in fact, not the case. Aside from a type of Lundbeck's, specimens are before me that were caught in Alaska (St. Paul Isl.), Friday Harbor (Washington, U. S.), and in Behring Str. (Miednaja)."

Among some diptera obtained by several collectors in Labrador and Newfoundland I find only $F$. marina. Still there is little doubt but that $F$. fucorum is to be found on those shores, but very doubtful if it will be found as far South as New England. The following table comprises the four species from Eastern North America:-

\section{MALES.}

1. Posterior femora on the underside at the base with a thick tuft of short

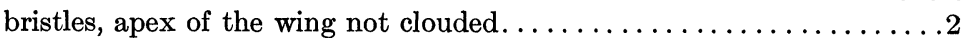
Posterior femora without the thickened tuft of bristles at the base, but on the underside along the whole length with rather strong bristles of nearly equal length, apex of the wing clouded....... pictipennis Beck. 
2. Middle tibiae without bristles on the inside, tibiae and palpi for the greater part reddish yellow, rarely darkened.......... marina Macq. Middle tibiae on the inside with one or two distinct bristles, palpi and

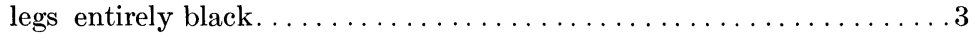

3. Posterior femora only on the underside with a rather small bristle tuft, halteres blood red.................... ariciiformis Holmgr. Posterior femora in addition to the bristle tuft, on the underside with a knob-like swelling turned toward the body and set with short bristles, halteres yellow.

fucorum Fall.

\section{FEMALES.}

1. Tibia for the most part yellow, tarsi and femora for the most part black, middle femora on the underside only with very fine, short hairs.

marina Macq.

Tibiae for the most part black. . . . . . . . . . . . . . . .

2. Posterior lower sternopleural bristles wholly wanting or only indicated by a quite fine short hair, apex of the wing distinctly clouded.

pictipennis Beck.

Posterior lower sternopleural bristles distinct even if short, apex of wing

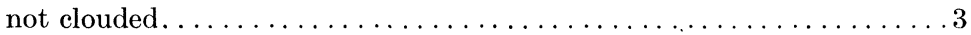

3. Middle femora only on the underside behind with a few longer bristlelike hairs, halteres yellow...................fucorum Fall. Middle femora not merely on the underside behind, but also on the underside in front with several comparatively strong bristle-like hairs, halteres blood red......................... ariciiformis Holmgr.

A study of all the original descriptions of the species suggested as synonyms by Prof. Stein, seems to point conclusively to the fact that the synonymy will have to stand as follows:-

\section{Fucellia marina Macquart.}

Scatophaga marina Macq., Ann. Soc. Ent., France, VIII, 242, pl. 11, fig. 3. Oct., 1838.

Scatophaga (Halithea) maritima Haliday, Ann. Nat. Hist., II, 186, Nov., 1838.

Fucellia arenaria Desv., Ann. Soc. Ent., France, X, 272, 1841.

Fucellia intermedia Lundbeck, Dipt. Groenl.,-Videns. Meddel. Nat. Foren., Kjoebenhaven, 1901, p. 291, fig. 1 b.

Fucellia maritima Stein, Wiener Ent. Zeit., XXIX, 18, 1910.

In referring to the synonymy in his introduction, Stein shows that the type of Fucellia is $F$. arenaria, the only species mentioned by 'Desvoidy under his generic diagnosis, and suggests that Desvoidy's statement that the female has the tuft of bristles on the posterior femora was undoubtedly a slip of the pen. Prof. Stein further states 
(as Mik has also done), that there are a number of species of Fucellia in which the posterior femora are simple in both sexes, and which yet belong to Fucellia beyond a doubt.

The specimens before me show the following distribution:-Great Caribou Isl., Iabrador, July 14th (G. M. Allen); Caribou Isl., Lab., (Packard); Funk Isl., Newfoundland, July (Owen Bryant); Eastport, Me., July 15 (Johnson); Dover, N. H., April 11 (Bridwell); Hampton, H. N. (Shaw); Beverly, Mass., April 24 (A. P. Morse); Framingham, Mass., June 6 (Frost); Cohasset, Sept. 8 (Bryant); Fall River, Mass., April 20 (N. S. Easton); Kingston, R. I., March 27 (Barlow); New Haven, Conn., Nov. 9 (Viereck); Clemonton, N. J., April 15, and Philadelphia, Pa., March 12 (Johnson); Bermuda, March 6 (F. M. Jones); St. Augustine and De Funiak Springs, Fla., March 1st (Johnson); Charlotte IIarbor, Fla. (Mrs. Slosson).

From the Pacific Coast Prof. Stein has described five new species:--Fucellia bicruciata, Behring Strait; F. costalis, Monterey, Cal.; $F$. antennata, Alaska; F. separata, Monterey, Cal. and Seattle, Wash., and F. rufitibia, Pacific Grove, Cal.

The Mating Habits of Empididae. Hamm, A. H. Observations on Empis livida L. Ent. Month. Mag. XIX, pp. 181-184; Observations on Empis opaca F., Ibid., XX, pp. 132-134; Further Observations on the Empinae, Ibid., XX, pp. 157-162.

It appears to be the regular occurrence among many species of Empis, and also in at least some species belonging to Pachymeria and Rhamphomyia, for the males to capture small Diptera and other insects which they paralyze with their beaks, and then offer to the females to feed upon during copulation. The male does not appear to partake of this food itself and simply offers it to the female which devours it while pairing. Several other species of Empis were found to copulate without prey, and females of these were found feeding at other times, although those which copulate with prey were not found to feed at other times.

C. T. B. 

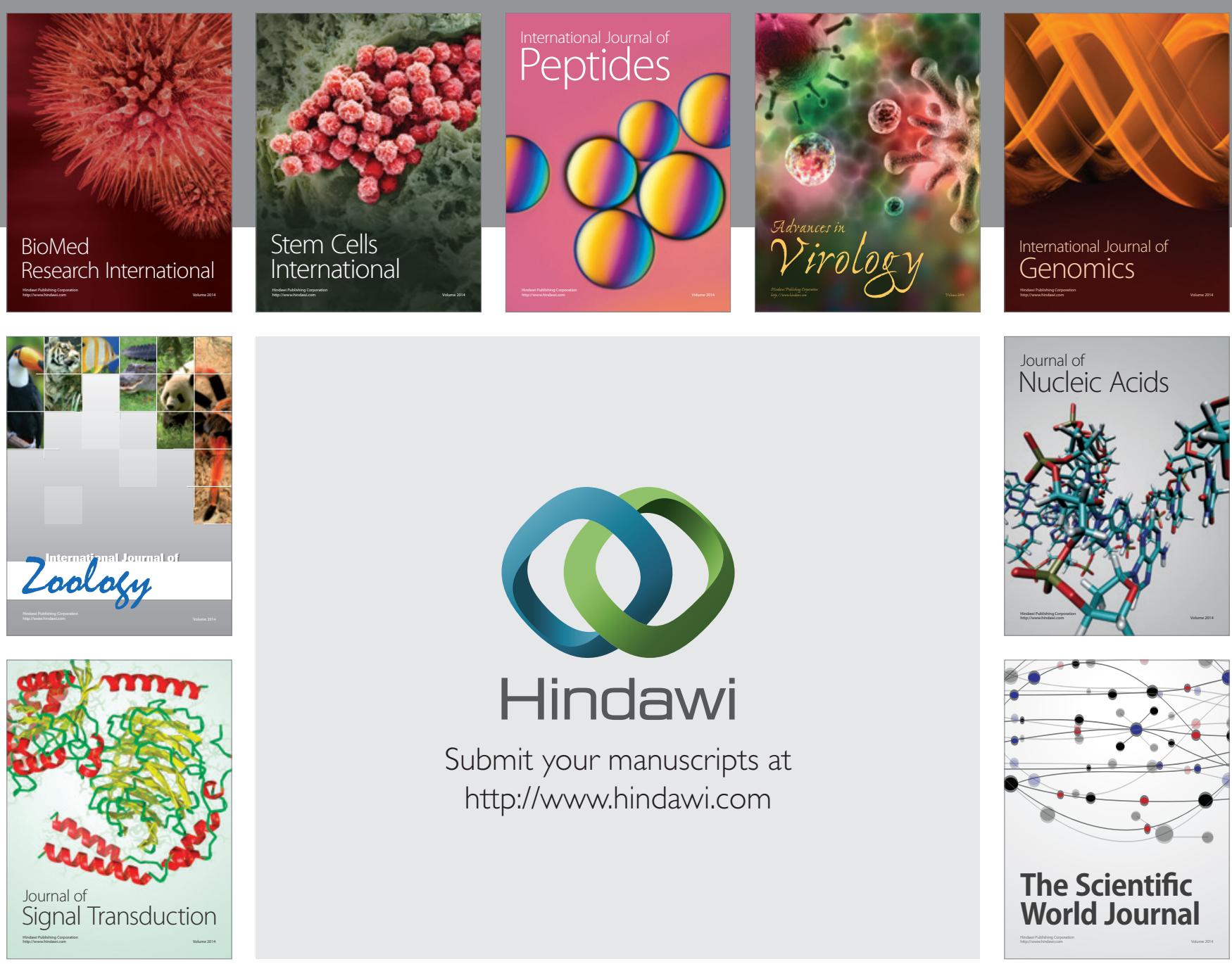

Submit your manuscripts at

http://www.hindawi.com
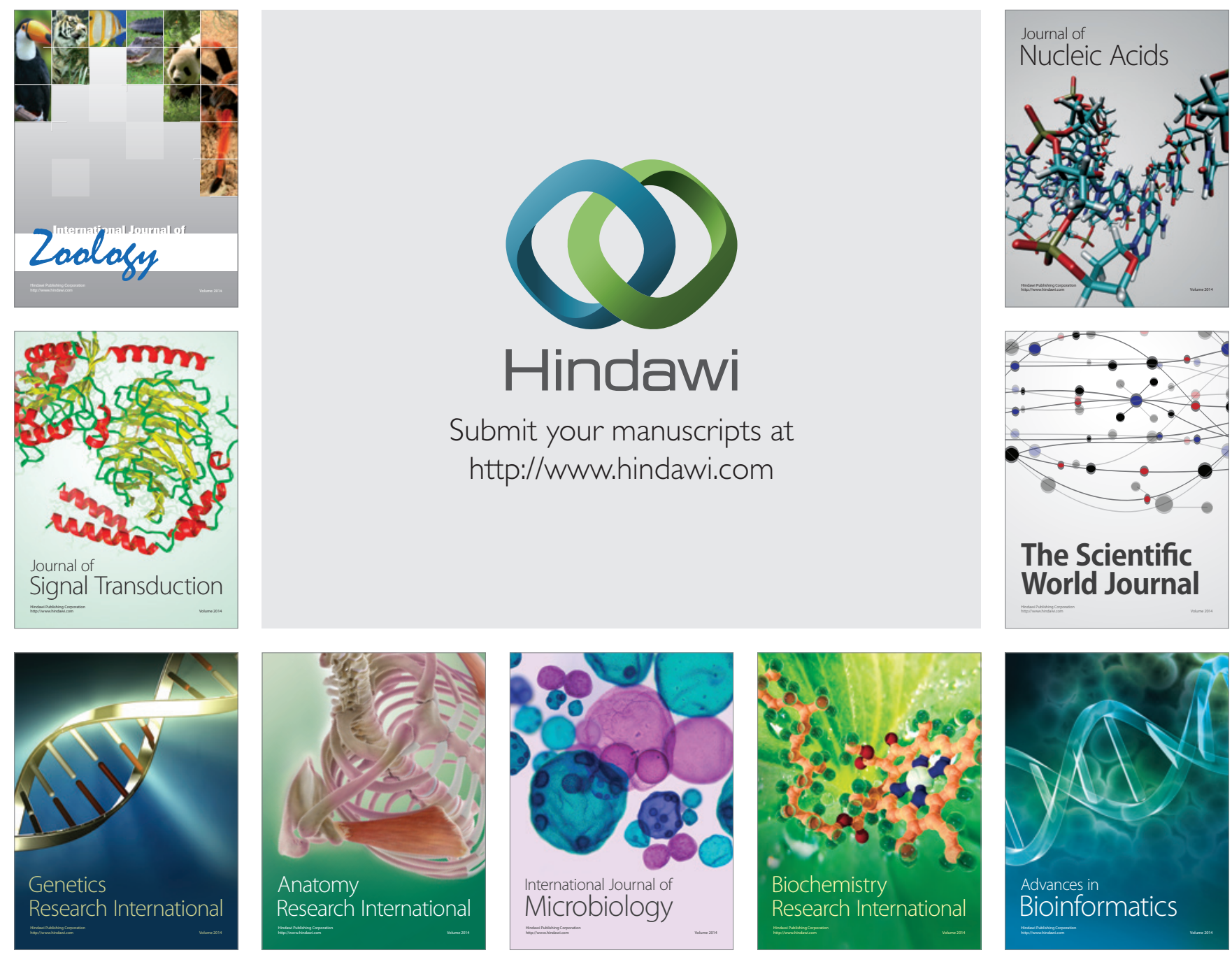

The Scientific World Journal
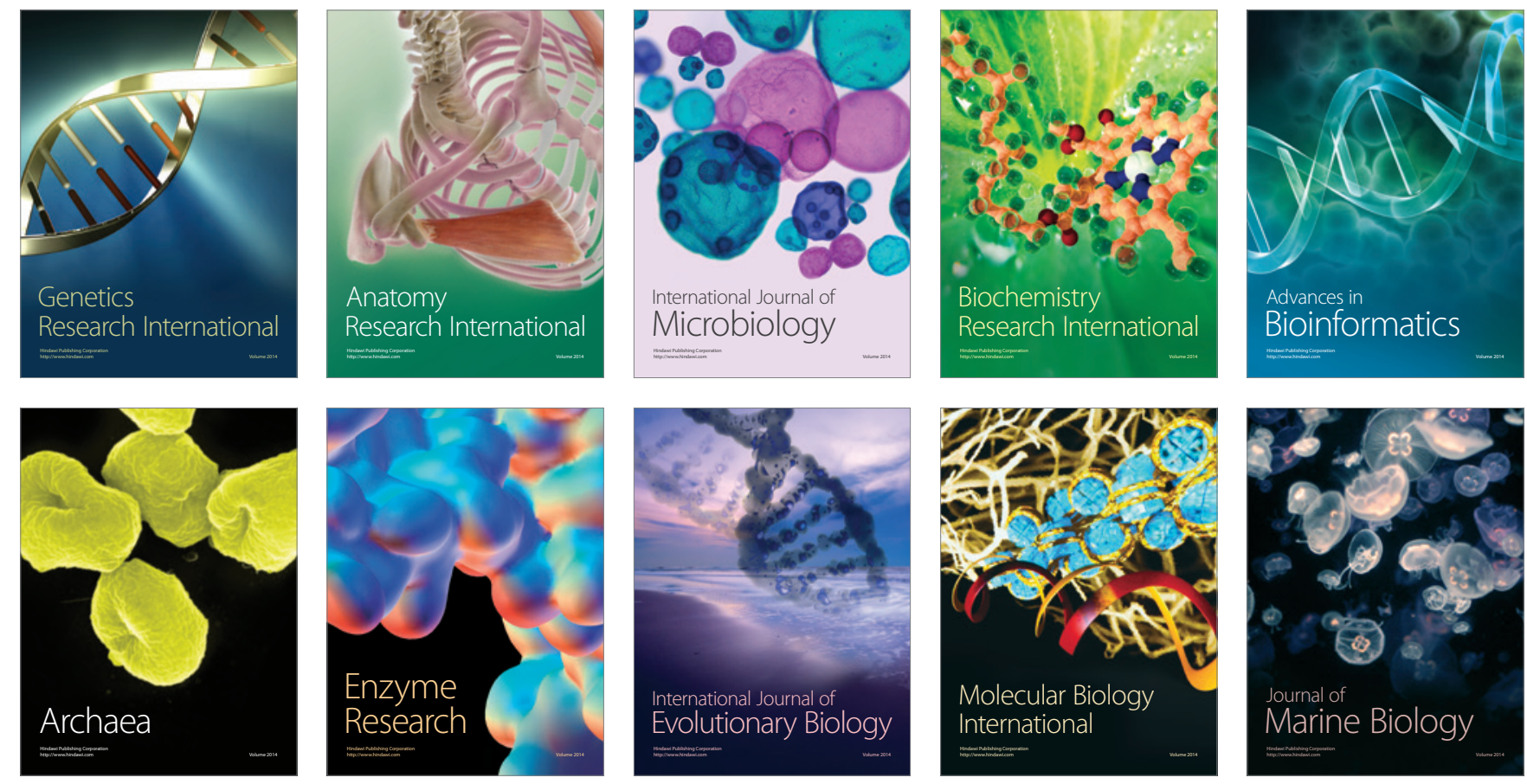